Research Article

\title{
A Magnetic Nanoparticle Labeled Immunochro- matography Kit for SARS-CoV-2 Infection Diagnosis
}

\author{
Qi Shen ${ }^{1 \dagger}$, Hui Liang ${ }^{1 \dagger}$, Jing Tian ${ }^{1}$, Cheng $\mathrm{Zhou}^{1}$, Ang $\mathrm{Gao}^{2}$, Dan Wang ${ }^{1}$, Jian $\mathrm{Ni}^{2}$, Daxiang Cui ${ }^{1,2}$ \\ ${ }^{1}$ National Engineering Research Center for Nanotechnology, 28 East Jiangchuan Road, Shanghai 200241, China. \\ ${ }^{2}$ Institute of Nano Biomedicine and Engineering, Shanghai Engineering Research Centre for Intelligent Diagnosis and Treatment \\ Instrument, Department of Instrument Science and Engineering, School of Electronic Information and Electrical Engineering, \\ Shanghai Jiao Tong University, 800 Dongchuan Road, Shanghai 200240, China. \\ ${ }^{\dagger}$ These authors contributed equally to this work. \\ Corresponding authors. E-mail: 13818096617@139.com; dxcui@sjtu.edu.cn
}

Received: Aug. 24, 2020; Accepted: Oct. 27, 2020; Published: Oct. 29, 2020

Citation: Qi Shen, Hui Liang, Jing Tian, Cheng Zhou, Ang Gao, Dan Wang, Jian Ni, and Daxiang Cui. A Magnetic Nanoparticle Labeled Immunochromatography Kit for SARS-CoV-2 Infection Diagnosis. Nano Biomed. Eng., 2020, 12(4): 325-330.

DOI: 10.5101/nbe.v12i4.p325-330.

\begin{abstract}
The novel coronavirus disease (COVID-19) is breaking out and spreading rapidly around the world. There is an urgent need for an accurate and rapid detection method to quickly find infected patients and asymptomatic carriers in order to prevent the spread of the severe acute respiratory syndrome coronavirus [SARS-CoV-2]. In this paper, we designed a test strip which used the principle of double antigen sandwich. $\mathrm{Fe}_{3} \mathrm{O}_{4}$ magnetic nanobeads are firstly coupled with specific antibodies, and the $\mathrm{S}$ protein of the new coronavirus is used as the coating antigen to capture specific antibodies against the new coronavirus, which is used to detect the virus nucleoprotein of specific antibodies in clinical samples. At the same time, $\mathrm{Fe}_{3} \mathrm{O}_{4}$ magnetic nanobeads have unique magnetic properties, which can be used to generate different types of detection signals and simplify the detection process. These results can be judged by color changes and magnetic changes at the test and control lines. Compared with the traditional method, this test strip of $\mathrm{Fe}_{3} \mathrm{O}_{4}$ magnetic nanobeads has high sensitivity and can qualitatively detect samples within 15 minutes. The magnetic performance of the magnetic nanobeads can be used to improve the sensitivity of the strip in our further research and product development.
\end{abstract}

Keywords: SARS-CoV-2, Magnetic Nanoparticle, $\mathrm{Fe}_{3} \mathrm{O}_{4}$ nanobeads, Immunochromatography

\section{Introduction}

The outbreak and rapid spread of the novel coronavirus disease (COVID-19) has had a huge impact on the whole world [1]. Although RT-PCR method has become the standard method for diagnosing SARS-CoV-2 infection [1], these methods have many limitations, such as the high false negative rate [2]. So, there is an urgent need for a fast and precise detection methods to screen out people infected with the virus and asymptomatic carriers.

At present, the diagnosis of SARS-CoV-2 at the molecular level includes nucleic acid detection methods and antigen/antibody immune detection methods [1, 4]. Nucleic acid-based detection methods include specific gene detection of viral nucleic acid and viral genome sequencing [4]. The nucleic acid detection kits have been approved for clinical use now, but there still has some limitations, such as cumbersome operation, long time consuming, need for centralized inspection 
and professional equipment, which greatly restricts the use and convenience of detection due to its high technical threshold [5]. And the false negative rate of nucleic acid testing is relatively high in clinical. The antibody detection method are mainly rapid diagnostic kits (colloidal gold method) for antibody IgG and IgM, using the $\mathrm{S}$ protein of new coronavirus as the coating antigen and labeling antigen to detect the specific antibodies of virus nucleoprotein in clinical samples [6]. This method does not need complicated equipment and it can qualitatively test samples in a very short time, so it is suitable for preliminary screening in primary hospitals. Further, we can use the magnetism of magnetic nanoparticles for quantitative detection instead of colloidal gold. There is no relevant quantitative detection product on the market.

Magnetic nanoparticles are a kind of magnetic material with a size of 1-100 nm [7]. It has unique optics, magnetism, electricity, thermal, mechanical and chemical activities, so it has a broad prospect in the diagnostic technology based on magnetic nanoparticles [8]. There are several kinds magnetic nanoparticles, such as cobalt oxide, nickel oxide, and iron oxide [9]. Among them, iron oxide nanoparticles have been widely studied in the field of biomedicine due to their good biocompatibility, biodegradability and superparamagnetic [10].

In this work, we have developed a specific test strips that can qualitatively and quantitatively detect the antibody (IgG and IgM) of new coronavirus (2019-nCoV) in serum by immunochromatography, and the high sensitivity and color rendering ability of $\mathrm{Fe}_{3} \mathrm{O}_{4}$ magnetic nanobeads gives the test strip a unique performance. IgM antibody positive means recently infected, IgG antibody positive means longer infection time or previously infected. The clinical test results show that the accuracy rate of the test strip we developed is over $90 \%$, and the result can be received within 5 minutes at the fastest. The structure of the test strip is shown in Fig. 1.

\section{Experimental}

\section{Materials}

Ferric trichloride $\left(\mathrm{FeCl}_{3}, 99 \%\right)$, Trisodium citrate ( $\mathrm{Na}_{3} \mathrm{Cit}, 99 \%$ ), Sodium acetate (NaAc, 99\%), Ethanol (99.5\%) were purchased from Sigma-Aldrich. 2-Morpholinoethanesulfonic acid (MES, 99\%), n-(3-dimethylaminopropyl)-n'-ethylcarbodiimide hydrochloride (EDC, 99\%), N-Hydroxysuccinimide (NHS, 99\%), Tween-20 (99\%), Boric acid (99\%), Sodium tetraborate (99\%) were purchased from Sinopharm Chemical Reagent Co., LTD. IgG and IgM antibody were purchased from Abcam. The positive and negative samples were purchased from National Institutes of Food and Drug Control.

\section{Preparation of $\mathrm{Fe}_{3} \mathrm{O}_{4}$ magnetic nanobeads}

Add $0.65 \mathrm{~g} \mathrm{FeCl}_{3}$ and $0.2 \mathrm{~g} \mathrm{Na}_{3} \mathrm{Cit}$ to $20 \mathrm{ml}$ of ethanol, stir until dissolved. Then add $1.2 \mathrm{~g}$ of NaAc and stir for 30 minutes. The mixed solution was added to a $50 \mathrm{ml}$ hydrothermal kettle and reacted at $200{ }^{\circ} \mathrm{C}$ for 10 hours. After being cooled to room temperature, the nanoparticles were aged and washed with $80 \%$ ethanol solution. Finally, put the precipitate in an oven at $50{ }^{\circ} \mathrm{C}$ for drying to obtain the magnetic bead powder.

\section{Preparation of immunomagnetic beads}

The whole preparation process includes four steps of activation, coupling, sealing and preservation. (1) Activation: Use $\mathrm{pH}$ 6.0, 0.01 M MES solution as the activation buffer solution. Took $10 \mathrm{mg}$ of carboxyl $\mathrm{Fe}_{3} \mathrm{O}_{4}$ magnetic nanobeads into a $2 \mathrm{~mL}$ centrifuge tube, added $1000 \mu \mathrm{L}$ activation buffer, mixed well on the vortex shaker, and then placed the centrifuge tube on the magnetic separation rack, when the $\mathrm{Fe}_{3} \mathrm{O}_{4}$ magnetic nanobeads were completely adsorbed, removed the supernatant. Then, added $1000 \mu \mathrm{L}$ activation buffer into the centrifuge tube to wash the magnetic beads twice. Added $200 \mu \mathrm{L} 5 \mathrm{mg} / \mathrm{mL}$ EDC and $200 \mu \mathrm{L} 5 \mathrm{mg} / \mathrm{mL}$ NHS into the $\mathrm{Fe}_{3} \mathrm{O}_{4}$ magnetic

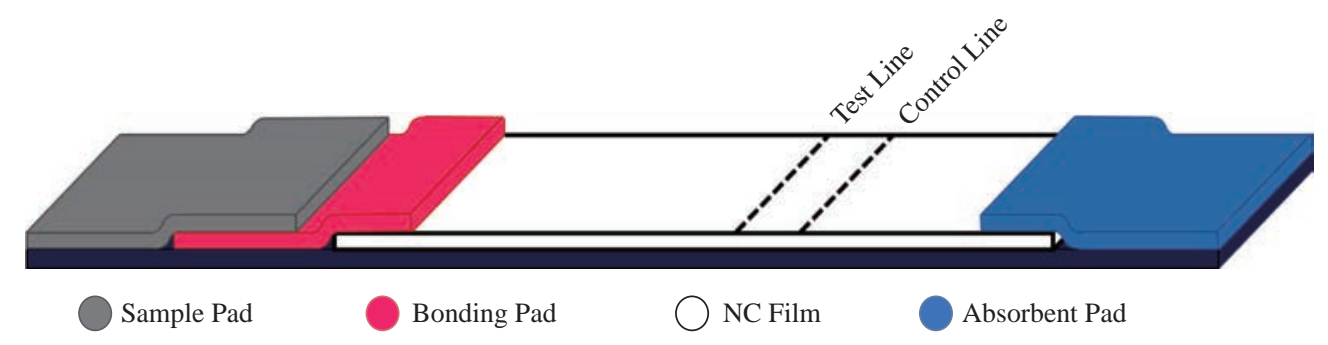

Fig. 1 The structure of the magnetic nanoparticle-based test strip. 
nanobeads. Mixed well on a vortex shaker, then activate the carboxyl groups on the surface of $\mathrm{Fe}_{3} \mathrm{O}_{4}$ magnetic nanobeads at $37{ }^{\circ} \mathrm{C}$ for 30 minutes. After activation, wash the $\mathrm{Fe}_{3} \mathrm{O}_{4}$ magnetic nanobeads with MES solution which was added $0.05 \%$ TWEEN-20 twice to remove extra EDC and NHS. (2) Coupling: use pH 9.0, 0.02 $\mathrm{M}$ borate Tween buffer $(0.05 \%$ Tween-20) solution as coupling buffer, washed the $\mathrm{Fe}_{3} \mathrm{O}_{4}$ magnetic nanobeads twice with $995 \mu \mathrm{L}$ coupling buffer and then added $5 \mu \mathrm{L}$ of $20 \mu \mathrm{g} / \mu \mathrm{L}$ Goat-anti-human IgG Fc and Goat-antihuman IgM mu chain antibody. The mixed solution was reacted at $37^{\circ} \mathrm{C}$ for 3 hours, and then subjected to shake at room temperature overnight to prepare antibody modified $\mathrm{Fe}_{3} \mathrm{O}_{4}$ magnetic nanobeads. After the coupling was completed, the reaction supernatant was collected and the amount of coupled protein was detected with the BCA kit. (3) Blocking: Added $1000 \mu \mathrm{L}$ of $1 \%$ BSA to block the activated groups on the surface of the immunomagnetic nanobeads that have not fully reacted for 30 minutes at room temperature to reduce the nonspecific combine that may occur in the future test. (4) Storage: Washed the blocked immunomagnetic beads with BST buffer for four times, and finally resuspend the magnetic beads in $1000 \mu \mathrm{L}$ preservation solution and stored in a refrigerator at $4{ }^{\circ} \mathrm{C}$.

\section{BCA method to detect the amount of coupling protein}

Dilute the standards with PBS to a final concentration of $0.5 \mathrm{mg} / \mathrm{mL}$, and take $0,1,2,4,8,12$, $16,20 \mu \mathrm{L}$ standard solution in the enzyme reaction well, each standard solution is repeated in parallel. Then add PBS to each well to a total volume of $20 \mu \mathrm{L}$, add $200 \mu \mathrm{L}$ of BCA reaction solution to all wells with standard solution or supernatant, gently mixed at 60 ${ }^{\circ} \mathrm{C}$ and react for 30 minutes. Finally use a microplate reader to detect the absorbance value of each well. Make a standard curve based on the concentration and absorbance of the standard solution, and then obtain the amount of antibody based on the absorbance of the supernatant, thereby obtaining the coupling amount of the antibody on the magnetic nanobeads surface.

\section{Preparation of test strips}

The test strip sample pad and the bonding pad are processed as follows: (1) Cut the glass fiber membrane into a size of $25 \mathrm{~mm} \times 5 \mathrm{~mm}$. In order to optimize the performance of the test strip, the sample pad needs to be pre-treated before construction. Soak the cut glass fiber membrane in PBST for half an hour. Then put the soaked sample pad in an oven at $37^{\circ} \mathrm{C}$ for 2 hours and then take it out for use. (2) Cut the glass fiber membrane into a size of $5 \mathrm{~mm} \times 5 \mathrm{~mm}$. Soak the cut glass fiber membrane with the binding pad treatment solution for 30 minutes. Sonicate the diluted immunomagnetic nanobeads solution for 5 minutes. Use a pipette to draw $15 \mu \mathrm{L}$ of the immunomagnetic bead solution, and evenly place it on the binding pad. Then put the bonding pad in an oven at $37{ }^{\circ} \mathrm{C}$ for 2 hours and then take it out for use. (3) The T line (SARS-CoV-2 spike antigen and the $\mathrm{N}$ protein epitope peptide), the $C$ line (Rabbit anti-goat IgG HL) have been draw on the NC film. Finally, the processed sample pad, binding pad, NC film and absorbent pad have been assembled and the test strips are cut into 4 mm wide test strips with a cutting machine.

\section{Sensitivity of test strips}

The positive standards P1-P10 and the negative standards N1-N7 are all national drug standards purchased from China Food and Drug Control Institute. Then use three batches of test strips to test the negative and positive standards to explore the sensitivity of test strips.

\section{Specificity of test strips}

Negative standard N1, positive standard P1, and positive standard P5 were selected as negative, weakly positive and positive samples. Interfering samples (hemoglobin, bilirubin, triglycerides) were prepared by artificial addition, and three batches of kits were used to test the influence of adding different concentrations of interfering samples to the experimental groups.

\section{Results and Discussion \\ Characterizations of $\mathrm{Fe}_{3} \mathrm{O}_{4}$ magnetic nanobeads}

As showed in Fig. 2, the preparation of $\mathrm{Fe}_{3} \mathrm{O}_{4}$ magnetic nanobeads had the uniform shape and the average size was $220 \mathrm{~nm}$.

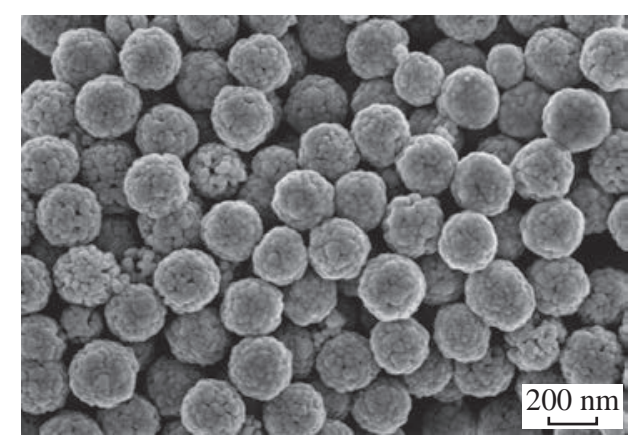

Fig. 2 The SEM image of $\mathrm{Fe}_{3} \mathrm{O}_{4}$ magnetic nanobeads. 


\section{Amount of coupled protein}

According to the absorbance value of the standard solution and the standard protein concentration, the standard curve of the standard protein concentration and absorbance can be obtained.

As shown in the Fig. 3, substitute the average value of three wells ( 0.156 a.u.) into the formula $\mathrm{Y}=0.6697 \mathrm{X}$ +0.1383 ( $\mathrm{Y}$ is the absorbance, $\mathrm{X}$ is the protein concentration) to calculate the sample supernatant with antigen concentration of $26.4 \mu \mathrm{g} / \mathrm{mL}$, so the coupling rate is $73.6 \%$.

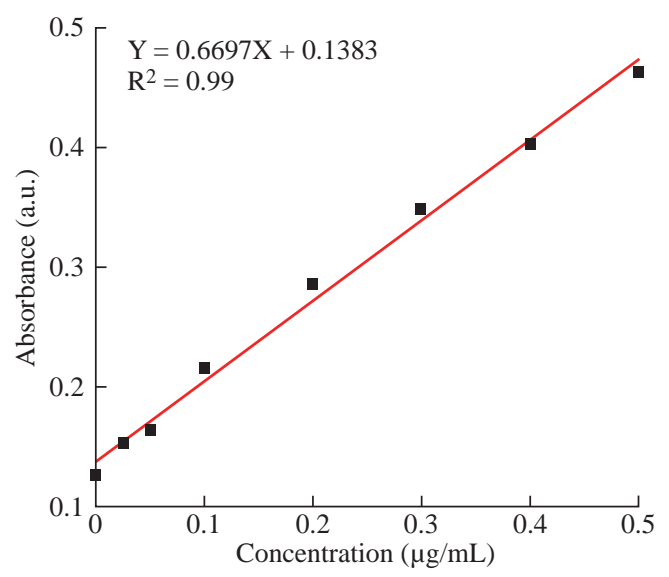

Fig. 3 The standard curve of protein concentration and absorbance.

\section{Sensitivity of test strips}

The experimental results are shown in Table 1.
Table 1 The coincidence rate of positive and negative samples

\begin{tabular}{|c|c|c|c|c|}
\hline \multicolumn{2}{|c|}{ Batch } & Lot1 & Lot2 & Lot3 \\
\hline \multicolumn{2}{|c|}{ Sample } & \multicolumn{3}{|c|}{ Results } \\
\hline \multirow{10}{*}{$\begin{array}{l}\text { Positive } \\
\text { Standards }\end{array}$} & $\mathrm{P} 1$ & $\mathrm{P}$ & $\mathrm{P}$ & $\mathrm{P}$ \\
\hline & P2 & $\mathrm{P}$ & $\mathrm{P}$ & $\mathrm{P}$ \\
\hline & P3 & $\mathrm{N}$ & $\mathrm{P}$ & $\mathrm{P}$ \\
\hline & P4 & $\mathrm{P}$ & $\mathrm{P}$ & $\mathrm{P}$ \\
\hline & P5 & $\mathrm{P}$ & $\mathrm{P}$ & $\mathrm{P}$ \\
\hline & P6 & $\mathrm{P}$ & $\mathrm{P}$ & $\mathrm{P}$ \\
\hline & P7 & $\mathrm{P}$ & $\mathrm{P}$ & $\mathrm{P}$ \\
\hline & P8 & $\mathrm{P}$ & $\mathrm{P}$ & $\mathrm{P}$ \\
\hline & P9 & $\mathrm{P}$ & $\mathrm{P}$ & $\mathrm{P}$ \\
\hline & P10 & $\mathrm{P}$ & $\mathrm{P}$ & $\mathrm{P}$ \\
\hline \multirow{7}{*}{$\begin{array}{l}\text { Negative } \\
\text { Standards }\end{array}$} & N1 & $\mathrm{N}$ & $\mathrm{N}$ & $\mathrm{N}$ \\
\hline & N2 & $\mathrm{N}$ & $\mathrm{N}$ & $\mathrm{N}$ \\
\hline & N3 & $\mathrm{N}$ & $\mathrm{N}$ & $\mathrm{N}$ \\
\hline & N4 & $\mathrm{N}$ & $\mathrm{N}$ & $\mathrm{N}$ \\
\hline & N5 & $\mathrm{N}$ & $\mathrm{N}$ & $\mathrm{N}$ \\
\hline & N6 & $\mathrm{N}$ & $\mathrm{N}$ & $\mathrm{N}$ \\
\hline & N7 & $\mathrm{N}$ & $\mathrm{N}$ & $\mathrm{N}$ \\
\hline
\end{tabular}

Three batches of kits were used to test 10 positive standards (P1-P10), all results were positive, and the positive coincidence rate was $100 \%$. The results of 7 negative standards (N1-N7) are all negative with a specificity of $100 \%$.

\section{Specificity of test strips}

The experimental results are shown in Table 2.

The test results showed that when negative samples,

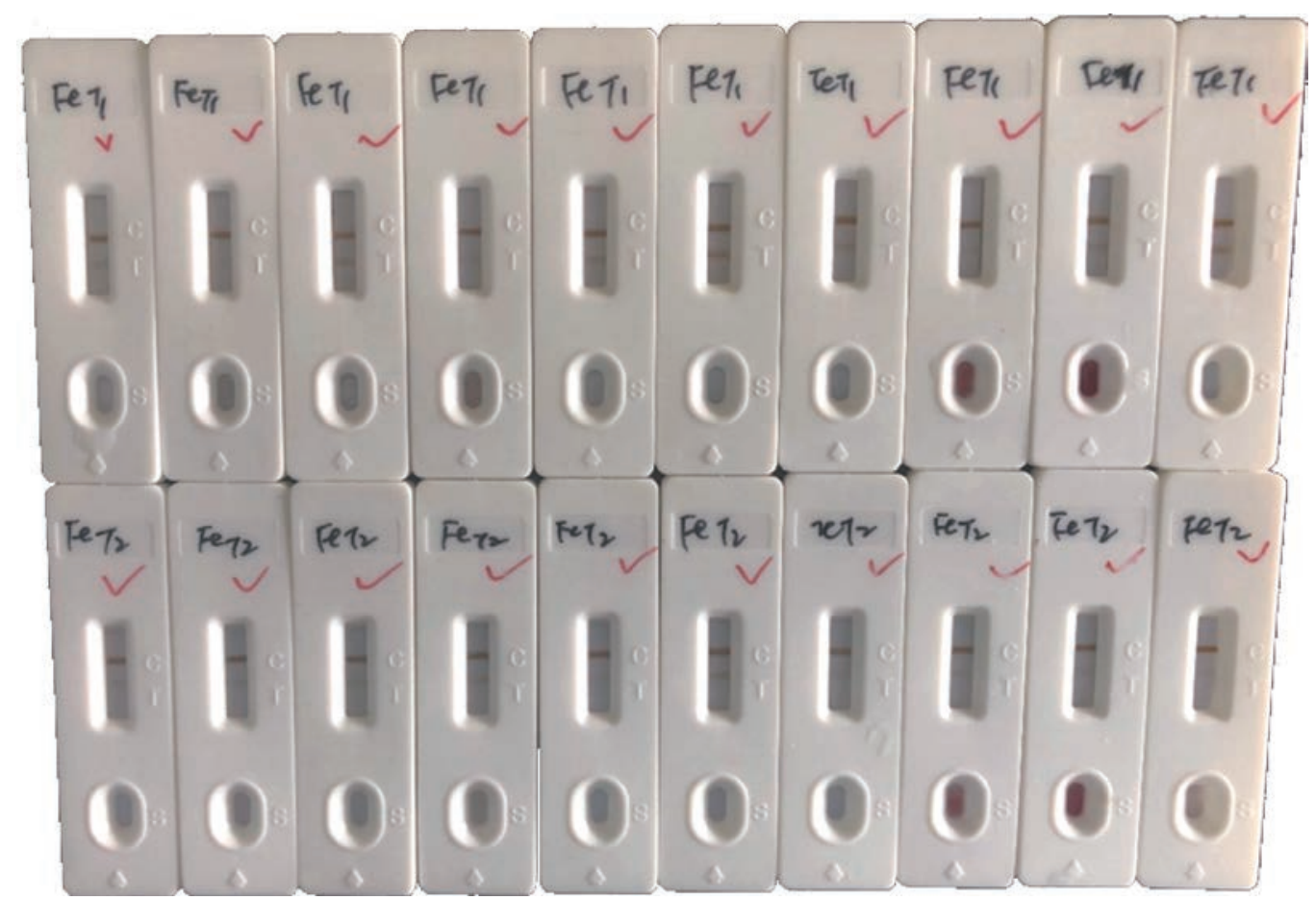

Fig. 4 Clinical results of the test strips. 
Table 2 The influence of different endogenous interferences on sample detection

\begin{tabular}{|c|c|c|c|c|c|c|c|c|c|c|c|}
\hline \multirow{3}{*}{\multicolumn{2}{|c|}{$\begin{array}{c}\text { Batch } \\
\text { Interfering substances } \\
\text { Samples }\end{array}$}} & \multicolumn{10}{|c|}{ Lot1 } \\
\hline & & \multirow{2}{*}{ None } & \multicolumn{3}{|c|}{ Hemoglobin (mg/mL) } & \multicolumn{3}{|c|}{ Triglycerides (mg/mL) } & \multicolumn{3}{|c|}{ Bilirubin (mg/mL) } \\
\hline & & & 1.25 & 2.5 & 5.0 & 6.25 & 12.5 & 25 & 0.05 & 0.1 & 0.2 \\
\hline \multirow{3}{*}{$\begin{array}{l}\text { Negative } \\
\text { samples }\end{array}$} & 1 & $\mathrm{~N}$ & $\mathrm{~N}$ & $\mathrm{~N}$ & $\mathrm{~N}$ & $\mathrm{~N}$ & $\mathrm{~N}$ & $\mathrm{~N}$ & $\mathrm{~N}$ & $\mathrm{~N}$ & $\mathrm{~N}$ \\
\hline & 2 & $\mathrm{~N}$ & $\mathrm{~N}$ & $\mathrm{~N}$ & $\mathrm{~N}$ & $\mathrm{~N}$ & $\mathrm{~N}$ & $\mathrm{~N}$ & $\mathrm{~N}$ & $\mathrm{~N}$ & $\mathrm{~N}$ \\
\hline & 3 & $\mathrm{~N}$ & $\mathrm{~N}$ & $\mathrm{~N}$ & $\mathrm{~N}$ & $\mathrm{~N}$ & $\mathrm{~N}$ & $\mathrm{~N}$ & $\mathrm{~N}$ & $\mathrm{~N}$ & $\mathrm{~N}$ \\
\hline \multirow{3}{*}{$\begin{array}{c}\text { Weak } \\
\text { positive } \\
\text { samples }\end{array}$} & 1 & $P$ & $\mathrm{P}$ & $\mathrm{P}$ & $\mathrm{P}$ & $\mathrm{P}$ & $P$ & $\mathrm{P}$ & $\mathrm{P}$ & $\mathrm{P}$ & $\mathrm{P}$ \\
\hline & 2 & $\mathrm{P}$ & $\mathrm{P}$ & $\mathrm{P}$ & $\mathrm{P}$ & $\mathrm{P}$ & $\mathrm{P}$ & $\mathrm{P}$ & $\mathrm{P}$ & $\mathrm{P}$ & $\mathrm{P}$ \\
\hline & 3 & $\mathrm{P}$ & $\mathrm{P}$ & $\mathrm{P}$ & $\mathrm{P}$ & $\mathrm{P}$ & $\mathrm{P}$ & $\mathrm{P}$ & $\mathrm{P}$ & $\mathrm{P}$ & $\mathrm{P}$ \\
\hline \multirow{3}{*}{$\begin{array}{l}\text { Positive } \\
\text { samples }\end{array}$} & 1 & $\mathrm{P}$ & $\mathrm{P}$ & $\mathrm{P}$ & $\mathrm{P}$ & $\mathrm{P}$ & $\mathrm{P}$ & $\mathrm{P}$ & $\mathrm{P}$ & $\mathrm{P}$ & $\mathrm{P}$ \\
\hline & 2 & $\mathrm{P}$ & $\mathrm{P}$ & $\mathrm{P}$ & $\mathrm{P}$ & $\mathrm{P}$ & $\mathrm{P}$ & $\mathrm{P}$ & $\mathrm{P}$ & $P$ & $\mathrm{P}$ \\
\hline & 3 & $\mathrm{P}$ & $\mathrm{P}$ & $\mathrm{P}$ & $\mathrm{P}$ & $\mathrm{P}$ & $\mathrm{P}$ & $\mathrm{P}$ & $\mathrm{P}$ & $\mathrm{P}$ & $\mathrm{P}$ \\
\hline \multicolumn{2}{|c|}{ Batch } & \multicolumn{10}{|c|}{ Lot2 } \\
\hline \multicolumn{2}{|c|}{ Interfering substances } & \multirow{2}{*}{ None } & \multicolumn{3}{|c|}{ Hemoglobin (mg/mL) } & \multicolumn{3}{|c|}{ Triglycerides (mg/mL) } & \multicolumn{3}{|c|}{ Bilirubin (mg/mL) } \\
\hline Sam & & & 1.25 & 2.5 & 5.0 & 6.25 & 12.5 & 25 & 0.05 & 0.1 & 0.2 \\
\hline \multirow{3}{*}{$\begin{array}{l}\text { Negative } \\
\text { samples }\end{array}$} & 1 & $\mathrm{~N}$ & $\mathrm{~N}$ & $\mathrm{~N}$ & $\mathrm{~N}$ & $\mathrm{~N}$ & $\mathrm{~N}$ & $\mathrm{~N}$ & $\mathrm{~N}$ & $\mathrm{~N}$ & $\mathrm{~N}$ \\
\hline & 2 & $\mathrm{~N}$ & $\mathrm{~N}$ & $\mathrm{~N}$ & $\mathrm{~N}$ & $\mathrm{~N}$ & $\mathrm{~N}$ & $\mathrm{~N}$ & $\mathrm{~N}$ & $\mathrm{~N}$ & $\mathrm{~N}$ \\
\hline & 3 & $\mathrm{~N}$ & $\mathrm{~N}$ & $\mathrm{~N}$ & $\mathrm{~N}$ & $\mathrm{~N}$ & $\mathrm{~N}$ & $\mathrm{~N}$ & $\mathrm{~N}$ & $\mathrm{~N}$ & $\mathrm{~N}$ \\
\hline \multirow{3}{*}{$\begin{array}{c}\text { Weak } \\
\text { positive } \\
\text { samples }\end{array}$} & 1 & $\mathrm{P}$ & $\mathrm{P}$ & $\mathrm{P}$ & $\mathrm{P}$ & $\mathrm{P}$ & $\mathrm{P}$ & $\mathrm{P}$ & $\mathrm{P}$ & $\mathrm{P}$ & $\mathrm{P}$ \\
\hline & 2 & $\mathrm{P}$ & $\mathrm{P}$ & $\mathrm{P}$ & $\mathrm{P}$ & $\mathrm{P}$ & $\mathrm{P}$ & $\mathrm{P}$ & $\mathrm{P}$ & $\mathrm{P}$ & $\mathrm{P}$ \\
\hline & 3 & $\mathrm{P}$ & $\mathrm{P}$ & $\mathrm{P}$ & $\mathrm{P}$ & $P$ & $\mathrm{P}$ & $\mathrm{P}$ & $\mathrm{P}$ & $\mathrm{P}$ & $\mathrm{P}$ \\
\hline \multirow{3}{*}{$\begin{array}{l}\text { Positive } \\
\text { samples }\end{array}$} & 1 & $\mathrm{P}$ & $\mathrm{P}$ & $\mathrm{P}$ & $\mathrm{P}$ & $\mathrm{P}$ & $\mathrm{P}$ & $\mathrm{P}$ & $\mathrm{P}$ & $\mathrm{P}$ & $\mathrm{P}$ \\
\hline & 2 & $\mathrm{P}$ & $\mathrm{P}$ & $\mathrm{P}$ & $\mathrm{P}$ & $\mathrm{P}$ & $\mathrm{P}$ & $\mathrm{P}$ & $\mathrm{P}$ & $\mathrm{P}$ & $\mathrm{P}$ \\
\hline & 3 & $\mathrm{P}$ & $\mathrm{P}$ & $\mathrm{P}$ & $\mathrm{P}$ & $\mathrm{P}$ & $\mathrm{P}$ & $\mathrm{P}$ & $\mathrm{P}$ & $\mathrm{P}$ & $\mathrm{P}$ \\
\hline \multicolumn{2}{|c|}{ Batch } & \multicolumn{10}{|c|}{ Lot3 } \\
\hline \multicolumn{2}{|c|}{ Interfering substances } & \multirow{2}{*}{ None } & \multicolumn{3}{|c|}{ Hemoglobin (mg/mL) } & \multicolumn{3}{|c|}{ Triglycerides (mg/mL) } & & in $(\mathrm{m}$ & \\
\hline Sam & & & 1.25 & 2.5 & 5.0 & 6.25 & 12.5 & 25 & 0.05 & 0.1 & 0.2 \\
\hline & 1 & $\mathrm{~N}$ & $\mathrm{~N}$ & $\mathrm{~N}$ & $\mathrm{~N}$ & $\mathrm{~N}$ & $\mathrm{~N}$ & $\mathrm{~N}$ & $\mathrm{~N}$ & $\mathrm{~N}$ & $\mathrm{~N}$ \\
\hline $\begin{array}{l}\text { Negative } \\
\text { samples }\end{array}$ & 2 & $\mathrm{~N}$ & $\mathrm{~N}$ & $\mathrm{~N}$ & $\mathrm{~N}$ & $\mathrm{~N}$ & $\mathrm{~N}$ & $\mathrm{~N}$ & $\mathrm{~N}$ & $\mathrm{~N}$ & $\mathrm{~N}$ \\
\hline & 3 & $\mathrm{~N}$ & $\mathrm{~N}$ & $\mathrm{~N}$ & $\mathrm{~N}$ & $\mathrm{~N}$ & $\mathrm{~N}$ & $\mathrm{~N}$ & $\mathrm{~N}$ & $\mathrm{~N}$ & $\mathrm{~N}$ \\
\hline & 1 & $\mathrm{P}$ & $\mathrm{P}$ & $\mathrm{P}$ & $\mathrm{P}$ & $\mathrm{P}$ & $\mathrm{P}$ & $\mathrm{P}$ & $\mathrm{P}$ & $\mathrm{P}$ & $\mathrm{P}$ \\
\hline positive & 2 & $\mathrm{P}$ & $\mathrm{P}$ & $\mathrm{P}$ & $\mathrm{P}$ & $\mathrm{P}$ & $\mathrm{P}$ & $\mathrm{P}$ & $\mathrm{P}$ & $\mathrm{P}$ & $\mathrm{P}$ \\
\hline $\mathrm{Sc}$ & 3 & $\mathrm{P}$ & $\mathrm{P}$ & $\mathrm{P}$ & $\mathrm{P}$ & $\mathrm{P}$ & $\mathrm{P}$ & $\mathrm{P}$ & $\mathrm{P}$ & $\mathrm{P}$ & $\mathrm{P}$ \\
\hline & 1 & $\mathrm{P}$ & $\mathrm{P}$ & $\mathrm{P}$ & $\mathrm{P}$ & $\mathrm{P}$ & $\mathrm{P}$ & $\mathrm{P}$ & $\mathrm{P}$ & $\mathrm{P}$ & $\mathrm{P}$ \\
\hline $\begin{array}{l}\text { Positive } \\
\text { samples }\end{array}$ & 2 & $\mathrm{P}$ & $\mathrm{P}$ & $\mathrm{P}$ & $\mathrm{P}$ & $\mathrm{P}$ & $\mathrm{P}$ & $\mathrm{P}$ & $\mathrm{P}$ & $\mathrm{P}$ & $\mathrm{P}$ \\
\hline & 3 & $\mathrm{P}$ & $\mathrm{P}$ & $\mathrm{P}$ & $\mathrm{P}$ & $\mathrm{P}$ & $\mathrm{P}$ & $\mathrm{P}$ & $\mathrm{P}$ & $\mathrm{P}$ & $\mathrm{P}$ \\
\hline
\end{tabular}

weak positive samples and positive samples were added with hemoglobin concentration of $5.0 \mathrm{mg} / \mathrm{mL}$, triglyceride concentration of $25 \mathrm{mg} / \mathrm{mL}$, and bilirubin concentration of $0.2 \mathrm{mg} / \mathrm{mL}$, the test result after adding interference sample is consistent with the test result without adding interference samples. Although lowconcentration interfering agents have no effect on the test results of the samples, red backgrounds may appear 
in hyperlipidemia, soluble samples and hemolytic samples, which will still affect the test results. It is still necessary to avoid the use of special samples.

\section{Clinical sample tests}

We have received 20 clinical samples of patients who have recovered from COVID-19 with anti-SARSCoV-2 IgM/IgG antibodies, dilute the serum according to the ratio required in the kit instructions, and the positive detection rate is $100 \%$.

\section{Conclusions}

In summary, the $\mathrm{Fe}_{3} \mathrm{O}_{4}$ magnetic nanobeads show the great potential to be the nanomaterial for the detection of SARS-CoV-2 instead of Nano-Au. The test strip of $\mathrm{Fe}_{3} \mathrm{O}_{4}$ magnetic nanobeads has high sensitivity and can qualitatively detect samples within 15 minutes according to the experiment. Also, the $\mathrm{Fe}_{3} \mathrm{O}_{4}$ magnetic nanobeads have unique magnetic properties, so that can be used to generate different types of detection signals such as color signal and magnetic signal. We will further explore its magnetic signal response in immunochromatographic detection.

\section{Acknowledgements}

This work was supported by Key Basic Research Program of China (No. 2017YFA0205304), Nature Scientific Foundation of China (No. 81602184), and Medical Engineering Cross Project of Shanghai Jiao Tong University (YG2017ZD12). This work was also supported by "the Belt and Road" young scientist exchange program of the Science and Technology Commission of Shanghai (Grant No. 18410741600).

\section{References}

[1] J. Wu, J. Liu, X. Zhao, et al. Clinical Characteristics of Imported Cases of Covid-19 in Jiangsu Province: A Multicenter Descriptive Study. Clinical Infectious Diseases, 2020, 71(15): 706-712.

[2] T. Ai, Z. Yang, H. Hou, et al. Correlation of Chest CT and RT-PCR Testing in Coronavirus Disease 2019 (Covid-19) in China: A Report of 1014 Cases. Radiology, 2020, 296(2).

[3] H.A.S. Hashmi, H.M. Asif, Early Detection and Assessment of Covid-19. Frontiers in Medicine, 2020, 7.

[4] W. Liu, Q. Zhang, J. Chen, et al. Detection of Covid-19 in Children in Early January 2020 in Wuhan, China. The New England Journal of Medicine, 2020, 382(14): 13701371.

[5] W. Wang, Y. Xu, R. Gao, et al., Detection of Sars-CoV-2 in Different Types of Clinical Specimens. Jama, 2020, 323(18): 1843-1844.

[6] A.T. Xiao, Y.X. Tong, S. Zhang, et al., False Negative of RT-PCR and Prolonged Nucleic Acid Conversion in Covid-19: Rather Than Recurrence. Journal of Medical Virology, 2020.

[7] M. Shen Y. Zhou, J. Ye, et al., Recent Advances and Perspectives of Nucleic Acid Detection for Coronavirus. Journal of Pharmaceutical Analysis, 2020, 10(2): 97-101.

[8] A.H. Lu, E.L. Salabas, and F. Schüth, Magnetic Nanoparticles: Synthesis, Protection, Functionalization, and Application. Angewandte Chemie, 2007, 46(8): 12221244.

[9] S. Laurent, D. Forge, M. Port, et al., Magnetic Iron Oxide Nanoparticles: Synthesis, Stabilization, Vectorization, Physicochemical Characterizations, and Biological Applications. Chemical Reviews, 2008, 108(6): 20642110.

[10] P. Tartaj, M.D.P. Morales, S. Veintemillas-Verdaguer, et al., The Preparation of Magnetic Nanoparticles for Applications in Biomedicine. Journal of Physics D, 2003, 36(13): 182-197.

Copyright $($ Qi Shen, Hui Liang, Jing Tian, Cheng Zhou, Ang Gao, Dan Wang, Jian Ni, and Daxiang Cui. This is an open-access article distributed under the terms of the Creative Commons Attribution License, which permits unrestricted use, distribution, and reproduction in any medium, provided the original author and source are credited. 